\title{
Digitalization of Consumption in Russia: Online Platforms, Regulations and Consumer Behavior
}

\author{
Olga Gurova and Daria Morozova
}

\begin{abstract}
13.1 INTRODUCTION
Digital consumption is a complex field that can be defined as "online retail, marketing approaches, or seen as an expanding field of technological platforms and mobile applications that advance various forms of production, distribution, and consumption" (Ruckenstein 2017, 562). Within Russian studies, this is a still emerging field. At the moment, scholarship on digital consumption in Russia is quite limited, although think tanks and marketing companies have been following the situation closely and provide the most up-to-date data.

In this chapter, we focus on two main topics within digital consumption which have emerged from the two main areas of scholarly interest: online shopping and the sharing economy. Research into online shopping has examined e-commerce business models (Doern and Fey 2006), barriers and drivers of e-commerce (Daviy et al. 2018; Daviy and Rebiazina 2015), effects of national culture on e-commerce acceptance (Kim et al. 2016), and the emergence of one of the biggest Russian e-retailers-Ozon (Hawk 2002). The sharing economy has been studied from the point of view of its barriers and drivers in acceptance of services (Rebiazina et al. 2018) and of socio-cultural meanings of particular sharing platforms, such as the gift-giving platform DaruDar.org (Polukhina and Strelnikova 2014; Strelnikova and Polukhina 2014; Polukhina and Strelnikova 2015; Bocharova and Echevskaya 2014; Ivanenko et al. 2014).
\end{abstract}

In alphabetical order, contribution of both authors is equal.

O. Gurova $(\varangle) \bullet$ D. Morozova

Aalborg University, Aalborg, Denmark

e-mail: gurova@hum.aau.dk; morozova@hum.aau.dk

(C) The Author(s) 2021

D. Gritsenko et al. (eds.), The Palgrave Handbook of Digital Russia

Studies, https://doi.org/10.1007/978-3-030-42855-6_13 
Whereas marketing researchers mainly apply online quantitative surveys, sociologists utilize qualitative methods - in particular, netnography or online ethnographic research (Kozinets 2010) complemented by face-to-face interviews. Of the marketing companies and think tanks providing data, we are drawing upon studies conducted by Morgan Stanley (2018), PayPal Inc. (2018), Russian Association of Internet Trade Companies (2017) and Data Insight $(2014,2017,2018,2019)$. Therefore, for this chapter we utilized three types of data: academic articles on the subject; research produced by think tanks and marketing companies; and media publications to identify the current trends in digital consumption in Russia.

The first section of the chapter focuses on e-commerce, while the second section sheds light on the sharing economy. Each section contains definitions and brief theoretical concepts related to the phenomena and concrete empirical examples taken from the context of digital consumption in Russia. In conclusion, we summarize the findings and suggest directions for future research.

\subsection{E-commerce, M-commerce and Online Shopping}

Digital transformations of retail and shopping are linked to the shift from offline to online retail (e-commerce, $\mathrm{m}$-commerce) and various forms of their co-existence. E-commerce is broadly defined as "using the internet to sell products and services" (Doern and Fey 2006, 315). M-commerce refers to purchases made from mobile devices such as smartphones and tablets. These transformations are enabled by the emergence of digital solutions for retailers and consumers, which transform the traditional offline retail and shape the everyday shopping experience. Digital transformations of retail and shopping occur in the context of a broader transition to the "service economy," where retailers act as "integrators of services" based on knowledge-intensive service innovations (Pantano and Gandini 2018, 1). This results in a new concept of retail that "overcomes the traditional physical boundaries of the store ... to foster the growth of new forms of commerce strongly based on the usage of technologies such as online and mobile for shopping" (ibid., 1).

Digital transformations of retail in Russia can be approached through the concept of "liquid retail," that is an open metaphor that helps to problematize the dynamics of retail, with the purpose of shedding light on the current circumstances in which retail stakeholders and consumers navigate the accelerated transformations (de Kervenoael et al. 2018, 417-418). Following this framework, in this section we pay attention to macro-level changes of market transformations, normative shifts, techno-economic (infra)structures and meso- and micro-level activities of multiple actors (new retail formations, changing consumption practices, etc.) (ibid., 418) in order to reflect upon how digitalization has changed retail and shopping in Russia. 


\subsubsection{E-commerce, M-commerce}

E-commerce has been acknowledged as one of the fastest growing markets in Russia. According to Statista, e-commerce is expected to show an annual growth of $7.5 \%$ in the coming years (Ecommerce Foundation 2018). In 2018, it was considered to be in an emerging state, with high potential for contributing to the development of the Russian national economy (Daviy and Rebiazina 2015,4 ). As for m-commerce, statistics (Ipiev 2018) show the share of mobile payments by July 2018 rose by $11 \%$ compared to the first half of the year. At the same time, the number of payments from desktop computers dropped by $4 \%$. Nevertheless, $55 \%$ of e-commerce purchases were made from desktop and $45 \%$ from smartphones and tablets. Yet, the number is expected to change in favor of $\mathrm{m}$-commerce, since retailers actively continue developing shopping apps and platforms for mobile devices (ibid.). In addition, shopping with an emphasis on "social commerce"-meaning shopping on social media-has become a noticeable phenomenon (Pantano and Gandini 2018, 2). According to research conducted by Yandex.Kassa and Data Insight, near 39 million Russians made purchases in various peer-to-peer platforms, such as social media and messengers (Yandex Kassa and Data Insight 2018).

There was virtually no e-commerce in Russia prior to 1998 (Hawk 2002, 702). It started to gain popularity after the Russian financial crisis of 1998, which forced many people to become self-employed and turned out to be a catalyst for entrepreneurial activities. The crisis was one of the reasons for the companies to start to operate more efficiently and develop e-solutions. As for other factors, such as internet penetration rate and access to computers, Hawk $(2002,703)$ mentions that the Internet usage in Russia was still very low at the time. Interestingly, the majority of those who accessed Internet did it at work (57\%), whereas only $27 \%$ accessed it at home. Between 1998 and 1999, the number of dot-com companies in Russia grew from 50 to 400 (Doern and Fey 2006, 317). Compared to the developed economies of the United States, Canada and Western Europe at this time, in developing countries such as Russia, India and countries in Latin America, e-commerce was miniscule (Hawk 2004, 181).

In the years that followed, e-commerce developed rapidly and continued to boom in Russia up till 2013, though its growth slowed down during the financial crisis of 2008-2009 (Daviy and Rebiazina 2015, 9). As for the situation in the second half of the 2010s, the economic recession followed by the Crimea crisis in 2014 had a significant effect on the development of Russian e-commerce (Sadyki 2017, 1). On the one hand, these changes included a drop in gross domestic product (GDP), a decrease of buying capacity of consumers, and increased political risks for Western companies to operate in Russia due to sanctions and counter-sanctions implemented after the annexation of Crimea. At the same time, these changes helped push Russian companies into the e-commerce market (ibid., 1). 
According to global ratings, Russia lags behind in terms of Internet penetration (23rd in 2017), reaching an estimated 62\% in 2018 (Ecommerce Foundation 2018, 13), with the majority of users concentrated in Moscow and major cities (Sadyki 2017, 2). The country was placed 99th in the United Nation's logistical performance list, 35th in its ease of doing business list, and 35 th in e-government Index (ibid., 14). In addition, there is a substantial gap in regional development across the country (Morgan Stanley 2018, 3). Considering these barriers, the Russian e-commerce market is characterized as under-developed and fragmented-for instance, the four major e-commerce players in Russia account for $27 \%$ of the market compared to $63 \%$ in the United States and $84 \%$ in China (ibid., 6), it is regionally highly disproportionate, and dominated by cash payments and poor quality of service, especially delivery (Sadyki 2017).

One of the drivers of e-commerce has been the increase of the quality and availability of Internet connections in Russian regions. There have been significant improvements in the services provided by the Post of Russia-the main operator of delivery services. Further, the development of numerous services, online payment platforms, digital signatures and a general increase in trust towards these types of tools contribute to e-commerce progress (ibid., 11).

\subsubsection{Russian E-commerce Retailers}

Digitalization and the development of e-commerce and $\mathrm{m}$-commerce have affected retailers of all sizes, from large- to small-scale. According to a report by Morgan Stanley $(2018,1)$, "Russia is the last major emerging market without a dominant online retailer." In the same report, it is estimated that the Russian e-commerce market will reach 31 billion dollars by 2020. In 2018, the two most influential actors on the Russian market were Yandex (the largest technological company specializing in internet products and services, including the search engine Yandex.ru) and the Mail.ru Group (a major technological company, operating the most popular Russian social networking sites VKontakte.ru, Odnoklassniki.ru and "Moj mir" [My.mail.ru]). Yandex joined forces with the largest state-owned bank, Sberbank, in order to create "a leading e-commerce ecosystem" based on the existing Yandex marketplace (Henni 2017). On the other hand, Mail.ru Group partnered with Chinese retail giant Alibaba, the owner of Aliexpress.com-the most popular online platform in Russia-to develop a "one-stop platform for social communication, gaming and shopping" (Henni 2018).

Meanwhile, some of the largest international e-commerce retailers have not been successful in their attempt to conquer the Russian market. eBay.com entered Russia in 2011, but so far has failed to gain significant traction. JD. com-China's second largest e-commerce player-left Russia in 2016 after just one year of operating. Among the main challenges, the executives of the company listed cross-border logistics and high marketing expenses (Sun 2018). In 2018, a number of German e-commerce giants such as Otto, Quelle and Westwing ceased their activity in Russia due to reduced purchasing power of 
consumers and significant revenue drops after converting funds from rubles into euros (East-West Digital News 2018). This latter phenomenon resulted from serious Russian ruble depreciation after 2014 (Urbanovsky 2015). The notable exception is Aliexpress.com, which has been one of the leaders on Russian online market, and will be discussed in more detail in the section on cross-border shopping.

At the same time, digital transformations in retail gave a significant boost to Russian small-scale innovative companies and startups-for instance, in fashion. Online retailing has various benefits: it allows these companies to reduce costs associated with launching and operating their businesses; it gives the opportunity to be discovered by consumers more quickly; it allows using new business models and flexibility in adjusting to fluctuations of the market; it gives data and instruments for the immediate analysis of consumer behavior; and, it also provides tools for immediate interaction with consumers through videos, blogs, messages. In a separate study, we noticed a "boost" in small-scale fashion businesses (Gurova and Morozova 2018) when startup companies created formal and informal businesses through social networks, using Instagram or VKontakte as sales channels.

\subsubsection{New Retail Platforms}

Digital transformations have globally led to the development of online retail platforms (Daviy and Rebiazina 2015; Doern and Fey 2006). The fastestgrowing and most highly valued e-commerce platform in Russia has been Wildberries.ru, an online platform for selling clothes, accessories, home goods and so on. The platform operates in Russia, Belarus, Kazakhstan and Kyrgyzstan and has plans to enter the European Union market in 2019, starting with Poland (Ganzhur 2019). By 2019, Wildberries was ranked number one among online fashion retailers worldwide with the highest traffic volume, followed by H\&M and Zara (Popova 2019). Wildberries' revenues have soared, showing $85 \%$ growth in the first three months of 2019 compared to the same period in 2018 (Intellinews 2019). Their fastest growing segments have been electronics, office equipment, gardening equipment and kitchen equipment (Kommersant 2019). The co-owner of Wildberries, Vladislav Bakalchuk, admits that their strongest advantages are the wide network of delivery points across Russia (with fewer couriers and the possibility to try clothes on the spot), and its commission model in which a supplier/producer pays commission for every sale (Kommersant 2018b). In 2018, the second and third most popular e-commerce sites in Russia were Ozon.ru (one of the leading multicategory retailer, offering goods in about 20 categories, including electronics, household appliances, clothes, food, Digital Versatile Discs (DVDs) and Citilink.ru (an online platform that positions itself as an electronics discounter), respectively (Kommersant 2018c).

Online retail platforms in Russia can be classified into seven categories (see Table 13.1). We have taken mostly examples from the list of top-100 companies in e-commerce in Russia in 2018 (Data Insight 2019) to illustrate the 
Table 13.1 Classification of online retail platforms in Russia

\begin{tabular}{|c|c|c|c|}
\hline No & E-Format & Description & Examples \\
\hline 1 & $\begin{array}{l}\text { Price-based online } \\
\text { platforms }\end{array}$ & $\begin{array}{l}\text { Platforms that have price as the } \\
\text { main strategy for differentiation }\end{array}$ & $\begin{array}{l}\text { Citilink.ru (electronics discounter); } \\
\text { KupiVIP.ru (discounter of } \\
\text { premium garment brands); } \\
\text { Kuponator.ru (discount coupon } \\
\text { service) }\end{array}$ \\
\hline 2 & $\begin{array}{l}\text { Community } \\
\text { forming retailers }\end{array}$ & $\begin{array}{l}\text { Platforms that incorporate } \\
\text { community activities, such as } \\
\text { forums and discussion boards }\end{array}$ & $\begin{array}{l}\text { Exist.ru, the biggest retailer for car } \\
\text { parts, has forum on their website }\end{array}$ \\
\hline 3 & $\begin{array}{l}\text { Online } \\
\text { marketplaces/ } \\
\text { shopping centers }\end{array}$ & $\begin{array}{l}\text { Platforms that offer an online } \\
\text { retail infrastructure for other } \\
\text { companies to sell their products }\end{array}$ & $\begin{array}{l}\text { Wildberries.ru sells clothes, } \\
\text { accessories, home goods; } \\
\text { Ozon.ru offers goods in about } 20 \\
\text { categories }\end{array}$ \\
\hline 4 & $\begin{array}{l}\text { Online department } \\
\text { stores }\end{array}$ & $\begin{array}{l}\text { Online equivalent of brick-and- } \\
\text { mortar department stores }\end{array}$ & $\begin{array}{l}\text { Tsum.ru, an online shop of Central } \\
\text { Universal Department store in } \\
\text { Moscow }\end{array}$ \\
\hline 5 & “Category killers" & $\begin{array}{l}\text { Price-aggressive retailers selling } \\
\text { a certain category of } \\
\text { commodities }\end{array}$ & $\begin{array}{l}\text { LaModa.ru sells clothes and shoes; } \\
\text { Mvideo.ru for electronics; } \\
\text { Petrovich.ru for homeware; } \\
\text { Online pharmacy Apteka.ru }\end{array}$ \\
\hline 6 & Niche retailers & $\begin{array}{l}\text { Websites selling a particular } \\
\text { type of goods }\end{array}$ & $\begin{array}{l}\text { Yamaguchi.ru offers massage } \\
\text { equipment }\end{array}$ \\
\hline 7 & $\begin{array}{l}\text { Micro-retailers of } \\
\text { social commerce }\end{array}$ & $\begin{array}{l}\text { Micro-companies that operate } \\
\text { predominantly on social media }\end{array}$ & $\begin{array}{l}\text { Roseville.ru is a fashion brand } \\
\text { selling women's clothes (being a } \\
\text { micro-brand, it is not included in } \\
\text { the top-100 list) }\end{array}$ \\
\hline
\end{tabular}

platform types. According to the top-100 list, among the top-10 companies are online marketplaces (Wildberries.ru, Ozon.ru), price-based online platforms (Citilink.ru) and "category killers"1 (Mvideo.ru for electronics, Lamoda.ru for clothes and Petrovich.ru for homeware).

In 2011, Darrell K. Rigby wrote about "omnichannel retailing." It refers to retailers who are "able to interact with customers through countless channels-websites, physical stores, kiosks, direct mail and catalogs, call centers, social media, mobile devices, gaming consoles, televisions, networked appliances, home services, and more" (Rigby 2011). Retailing in Russia is developing in the direction of omnichannel retailing. Therefore, in addition to traditional brick-and-mortar stores, companies operate as click-and-mortar stores, merging offline and online formats of retail in different ways. For instance, the online retailer Lamoda expressed its interest in opening the first offline store (Kommersant 2018a). Offline supermarket Perekrestok voiced a plan to launch a "shop-window" on its website where consumers can order commodities unavailable in the stores and offered by partners, and then pick them up in one of Perekrestok stores (Ishchenko 2018). Clothing online retailer Aizel.ru opened a pop-up store in the Moscow department store Atrium in 2018 (Utesheva 2018). However, managing director of KupiVIP.ru 
Miroslav Zubačevskij noted that although the omnichannel retailing is emerging in Russia, it is still underdeveloped and faces various problems, ranging from inconvenient Information Technologies (IT) solutions to logistical issues (Fashion United 2014).

An important dimension of the service economy is the consumer experience. Therefore, retailers use technological solutions to address the needs of retail and shopping as part of the experience economy (Pine and Gilmore 1998). Retailers actively use online tools to enhance the experiential dimension of shopping online with videos, blogs and other interactive formats. For example, Bonprix.ru has a rubric "Fashion and life" featuring news on current fashion trends and useful advice regarding fashion and lifestyle from editors and bloggers. At the same time, they aim at individualization or customization of experience and products. For instance, Vsemayki.ru offers to "construct" your own T-shirt with chosen print, while Holodilnik.ru offers the option of customizing the color and adding exclusive decorations on fridges, washing machines and dishwashers.

Augmented reality and virtual reality technologies are emerging trends in retailing, also in Russia (Utesheva 2018). For instance, the Russian company Mirow (Mirow.ru) developed a touch-screen mirror that is able to identify which items are taken to a fitting room and to give personal recommendations on what is usually bought or may suit with those items. It can also provide information about discounts, including personalized ones, offer to call a consultant or ask for a different size/color of an outfit, and to arrange the issuing of a loyalty card. Another technological solution, Tardis (Tardis3d.ru), helps to identify a customer's clothing size and the way outfit will look on their figure with the use of a selfie and a short questionnaire. There is also a startup, Fittin. $\mathrm{ru}$, that has developed virtual fitting for shoes. Although these solutions are to a large extent at the experimental stage, they are in line with global trends, with a direction towards "smart retail"- that is, the search for digital solutions for retail and further consumer acceptance of these solutions (Dacko 2017).

\subsubsection{The Profile of Online Consumers}

Between 2011 and 2014, major indicators of e-commerce in Russia were on the rise, including the quantity of orders and average purchase amount, followed by a substantial drop in 2015 (Data Insight 2017). However, after a steep decline, Russian e-commerce started to slowly recover, and as of 2018, $65 \%$ of the country's online users have shopped online at least once (Data Insight 2018).

As far as socio-economic characteristics are concerned, between 2011 and 2017, Russian trends remained typical for developing countries, where factors such as place of living, income and education have more influence on internet activity than physical access to the Internet (van Deursen et al. 2011; van Dijk and Hacker 2003). On the other hand, immaterial resources such as the knowledge of a foreign language and availability of free time may also influence the 
popularity of the online shopping (Firsova 2013,47). Interestingly, gender did not show significant correlation with the frequency of online shopping for a household; therefore, the researchers suggest that inconspicuousness of the online shopping (e.g. sitting alone in front of the monitor versus trying new clothes in public) might challenge the stereotype of shopping as a female prerogative (ibid., 48).

The leading group of online consumers, particularly in terms of frequency, are residents of megacities with higher education and above-average incomes, while poorer rural dwellers with less than 10 years' education lag behind (Data Insight 2018). However, experts (Morgan Stanley 2018; Data Insight 2018) assume that the current growth in online purchases is driven by shoppers from small towns, residential communities and villages who are quite price-conscious and have embraced online shopping in search of a better deal. Additionally, Russian rural settlements are now better equipped with pick-up points for online orders: in January $2017,76 \%$ of all delivery points were located in small towns and villages (Data Insight 2017). Furthermore, over half of Russian internet users make online payments and transfers: this indicator equals $61 \%$, $55 \%$ and $44 \%$ for large cities, middle-sized cities and the rest of the settlements, respectively (Data Insight 2018).

For a long time, the three most popular categories for online shopping have been electronics, clothing and household appliances (Russian Association of Internet Trade Companies 2017, 27). In addition to material goods, the popularity of food delivery, airplane and train tickets, as well as online games' complement products have been on the rise (Data Insight 2014).

The results of a poll by BrandMonitor, published in 2018, revealed that a large proportion of Russians (63\%) may mistake fakes for luxury brand items (Tishina 2018). An even larger proportion (84\%) of Russians shopping online is actually quite eager to buy counterfeit items (usually A-brands such as Apple or Louis Vuitton). As a rule, these consumers have some previous experience of buying fake goods through traditional channels, and afterwards turn to the Internet as an information tool. Frequently, the webpages of original brands are used as points of reference for comparing how well the fakes match the descriptions and pictures of authentic products (Radon 2012).

Overall, some pieces of research conclude (Firsova 2013) that the growth of the Internet shopping has great potential in Russia, but it will primarily spread among people who have previous positive experience of using the web.

\subsubsection{Online Cross-Border Shopping}

Online retail gives a boost to cross-border shopping. In 2015, 30\% of the Russian population made at least one online cross-border purchase in the course of the year (Ecommerce Foundation 2018). In 2017, 30\% of Russian online shoppers were limiting their purchases to the domestic market, whereas $56 \%$ were shopping both domestically and abroad, with 14\% abroad only (PayPal Inc. 2018). These shares of cross-border online purchases are among the highest in Eastern Europe (ibid.) 
Clothes and accessories, smartphones/tablets (including related items), home appliances and electronics have been the most popular goods for ordering abroad (Yandex 2016). The main reasons for cross-border shopping among Russians have been better deals in terms of price, wider selection of goods, and access to brands unavailable in Russia (ibid.), which corresponds to the crossborder shopping drivers among US (Invesp Consulting 2016) and European Union (EU) shoppers (Hunter and Wilson 2015, 25), but differs from Chinese consumers who are primarily interested in certified and authentic goods (Zhang 2018).

China has been the most popular country for cross-border orders in Russia, accounting for up to $80 \%$ of all cross-border sales in 2016 (East-West Digital News 2017, 22). In 2014, AliExpress became the number one e-commerce platform in Russia, and since then has been offering, in addition to Chinese goods, products made in Russia with a same-day delivery option and purchases on credit (ibid.). Honoring Russian-language consumers, the platform has translated its web-interface into Russian. However, the automated translation is not always grammatically correct or smooth and the descriptions of consumer goods can look like a mere collection of words without proper declension, for instance, "new fashion print design Russian crime tattoo." AliExpress gave rise to social media groups educating Russian consumers on how to navigate online shopping with the retailer. The company takes the Russian market seriously; it experimented with 3D virtual stores, and Russia is the only country where the retailer has tested an opportunity to enter the brick-and-mortar market (Vedomosti 2017).

\subsubsection{Regulation of the Online Cross-Border Shopping}

As online shopping has experienced noticeable growth, so did the number of purchases from the foreign platforms that have to cross the Russian border. As a result, substantial legislative changes regarding cross-border shopping have been introduced recently. From 2019, individual purchases with a price over 500 euro and weight over $25 \mathrm{~kg}$ are charged with a customs duty. Previously, customs duties were levied on individual purchases totaling over 1000 euro and weight over $31 \mathrm{~kg}$ per month. From 2020, this tax border for online crossborder shopping will be further decreased to 200 euro. Therefore, the direction of changes is to increase taxation by lowering the threshold amount for tax-free purchases. Experts and entrepreneurs working in the e-commerce sector question the necessity of this measure and predict low revenues to the government (Russia Business Today 2018; Skuratova 2018). As of 2018, very few online purchases in Russia exceed 200 euro, and $90 \%$ of receipts on the most popular platform AliExpress amount to less than 100 euro (Russia Business Today 2018).

Another legislative measure related to e-commerce offered by the Russian Association of Internet Trade Companies is the introduction of value added tax (VAT) for foreign online retailers. Arguing for this measure, the association maintains that the taxation of foreign e-retailers will support domestic 
companies (Russian Association of Internet Trade Companies 2018, for more, see also Chap. 5). In addition, in its statement, the Russian Association of Internet Trade Companies stresses that customs duties will bring approximately 300 million rubles to the Russian budget in the first three years (ibid.). The measure has so far been postponed due to a lack of agreement on how the procedure should be carried out technically. For instance, it is unclear if VAT should be paid by the online platform (e.g. AliExpress) or by the retailers that are using the platform. Experts argue that additional taxes may force international e-commerce platforms to cease their activity in Russia: equaling just $0.7 \%$, Russia is a minor player for world-wide operating companies (TASS 2017); additionally, foreign retailers are already paying operational costs, commission for using the online platforms and service providers' fees (Kommersant 2018d).

It is unclear how the new measures will influence cross-border shopping. In the meantime, new platforms are emerging to address the needs of the consumers. For instance, there is a Russian platform called Tudatuda.com where consumers gather to find someone who could buy and pass on a needed item from abroad. This service has been helpful for those looking for medicines or brands that are unavailable in Russia or when local prices are too high (for example, Apple products). ${ }^{2}$ Such practices suggest that, even if affected by the changes in legislation, cross-border shopping will most likely adjust, for instance, by changing its format.

\subsection{Online Exchanges: Sharing Economy and Collaborative Consumption}

The sharing economy and collaborative consumption refers to the collective use of consumer goods (Botsman and Rogers 2010) enhanced by the development of online platforms. Collaborative consumption is "the peer-to-peerbased activity of obtaining, giving, or sharing access to goods and services, coordinated through community-based online services" (Hamari et al. 2015, 2047). The sharing economy is an environment in which goods and services are offered and consumed through community-based platforms (ibid.). The terms can be used interchangeably since there are common denominators, namely, the mediating role of new digital technologies connecting various actors and modes of transfer. One position even argues that collaborative consumption is embedded in the sharing economy and is one of its forms (Wahlen and Laamanen 2017); therefore, we use sharing economy as the term embracing both categories.

The sharing economy has been triggered by the development of the Internet and technology, thanks to which it is easier to create trust between strangers (Botsman and Rogers 2010). There are other reasons for the growing popularity of the sharing economy, including economic (saving money), environmental (reducing ecological footprint) and social (expanding one's networks) (Schor and Thompson 2014). 
In Russia, the sharing economy has become a noticeable phenomenon for several reasons. On the one hand, its wider emergence has been linked to the financial crisis of 2008-2009, after which the use of many sharing services was a coping strategy of dealing with economic hardship. For example, the giftgiving platform DaruDar.org, launched in 2008, where participants make gifts of different daily objects such as books, children's products, furniture, homeware and others in exchange for gratitude, illustrate this copying strategy (Polukhina and Strelnikova 2014, 90). The boost of the sharing economy can also be seen as a result of people searching for alternative income sources during cutbacks. For instance, Youdo.com, launched in 2012, matches people who need minor home services (repair, cleaning) with service providers. The platform has been positioned as an opportunity to earn extra money in one's spare time and, on the other side, solve a home problem for a lower price.

At the same time, the proliferation of the sharing economy was connected to deeper socio-cultural processes in Russia. The first decade of 2010s was associated with the relative growth of well-being of Russian citizens ("fat noughties"); hence, there were people whose financial conditions made them eligible to participate in various lending and gift-giving activities. Bocharova and Echevskaya $(2014,102-103)$ have noticed that some people join DaruDar due to surplus rather than need, and share the motive of contributing to the common good. This is evidence of the fact that the increase in well-being resulted in a shift towards post-materialist values, among which are contributions to the common good, self-expression and environmentalism (Polukhina and Strelnikova 2014, 88). In addition, participation in the sharing economy has become a form of "consumer solidarity." Since the sharing economy is often a part of the "informal economy" (Polukhina and Strelnikova 2015), not directly regulated by the government (Polukhina and Strelnikova 2014, 87) and existing along with the "formal economy" of online stores (ibid.), it serves as a horizontal grassroots form of solidarity.

\subsubsection{Types of Sharing Economy}

Treapăt et al. (2018) distinguish between three types of sharing economy. The first one is paying for the benefit of using some good without purchasing it, such as the platform Rentmania.com launched in Moscow in 2013. The most popular items for borrowing (Shlyahov 2017) are children's goods; sports equipment; various gadgets, including laptops, game consoles, and scooters; and evening and carnival garments. Goods for borrowing are provided by both companies and individuals. The former dominates in the sector of larger sports equipment, such as treadmills, that is characterized by seasonal demand. The latter usually prevail in children's and gadget sectors. There are particular types of goods, such as photo booths, 3D printers or cotton-candy machines that are borrowed along with service providers. In addition, a separate and influential group of goods providers is comprised by winter downshifters, that is, people who leave Moscow for the whole winter period and are willing to offer 
long-term lease of their items. Rentmania was initially launched as a start-up with venture capital for Moscow region only. Without any interest from the consumers, it ceased its operation in Russia. In 2018, the owners of the platform decided to move from Russia to the United States due to lack of investors and, consequently, limited perspectives in the home market (Mihajlova 2018).

Another type of sharing economy is the redistribution of used and no longer needed goods to the users who need them, for money or exchange (Treapăt et al. 2018). In Russia, the most popular platform of this type is Avito.ru founded in 2007 by Jonas Nordlander and now owned by a South-African company, Naspers Holding. At first, Avito was a platform for re-selling various everyday products such as clothes, cutlery, furniture etc., but eventually it has expanded into other directions, including recruiting, real-estate and shortterm property leases. According to a Mediascope study (Ishunkina 2018), Avito's audience reached 4.3 million people aged between 12 and 64 years old by September 2018; and over 14 million Russians used Avito monthly with average 8 minutes per day (as of January 2019) (Mediascope 2019).

Finally, the third type of sharing economy is sharing of lifestyles, meaning that in addition to tangible goods, something intangible such as space and time is offered (Treapăt et al. 2018). Various rental services such as AirBnb.com are part of this type. In Russia, AirBnb has become popular in Moscow and St. Petersburg, showing growth of $121 \%$ between 2015 and 2016 (Egorova 2017). A research on AirBnb offers on Tverskaya street (Moscow) shows that Muscovites are renting out the rooms (40-72 euro per night) or apartments (69-120 euro per night) in Stalinist high rises for prices 5-15 times lower than hotels (from 499 euro per night) on the same street (Treapăt et al. 2018). On the one hand, Russians have been known for a quite conservative and protective attitude towards their homes ("My home is my castle"); on the other, they have a long history of sharing homes (kommunalka, a communal apartment in the former Soviet Union, typically shared by several families). According to Treapăt et al. (2018), apart from extra income, people in Russia are opening their flats in order to gain new experiences, broaden horizons and practice languages.

\subsubsection{Participants of Sharing Economy}

The proliferation of the Internet in Russia facilitated the increasing number of participants of various sharing services, spread far beyond one's close circle and scaling the sharing economy to a higher level. According to a survey by Data Insight (2018), 394 million transactions equaling 591 million rubles (7.5 million EUR) within the Russian sharing economy were conducted in 2018. The most popular product category was clothing and boots with an average transaction price of $1950 \mathrm{rub}$ ( $25 \mathrm{EUR}$ ). The second and third most popular categories were electronics and real estate. The online platform Avito was the most popular source for offering one's goods (65\% of users), followed by a similar platform Youla.ru (39\%), social networking site VKontakte (33\%), and Instagram (9\%) (ibid.). 
In relation to socio-demographic characteristics of consumers, researchers (Rebiazina et al. 2018) have shown that people aged 18-35 and those who live in big cities across Russia used services based on the sharing economy several times per month, while older generations (35-60) and residents of smaller towns used the services once every few months. The majority of consumers had an average income. The findings showed no difference between them and high-income consumers. Representatives of both income groups used services several times per month. Therefore, the sharing economy is a mostly urban phenomenon and is not linked to a particular income group. It has been found that the most popular services are Uber, GetTaxi and Avito, which were each used by 4 out of 10 people (ibid., 394).

\subsubsection{Drivers and Barriers of Sharing Economy}

Scholars have studied drivers and barriers of the use of services based on the sharing economy in Russia (Rebiazina et al. 2018). Regarding drivers, they found that although $60 \%$ of consumers trust the services and are ready to rent things, only $30 \%$ want to rent out their own things due to risks related to sharing, personal safety and hygiene. They also found that the ownership of things is considered to be a symbol of status; therefore, some consumers prefer to own things rather than to rent them (ibid., 394). Among the drivers, the following were named: (1) interest, comfort and utility towards/of sharing services, (2) recommendations of reference group (family, friends), (3) ecological and environmental benefits and (4) ease of use. Barriers included: (1) risks associated with participation in sharing, (2) additional efforts caused by participation (time, financial costs) and (3) preferences for ownership as an indicator of higher status. The researchers concluded that the companies willing to build their business in the Russian market should take into consideration the meaning of ownership as a status symbol and the necessity of building credibility and trust; a major issue in an emerging market (ibid., 397).

Noticeably, the researchers mostly discussed the sharing economy as a new phenomenon, coming from the Western countries and sometimes appearing in contradiction to the Russian mentality with its inclination towards ownership as opposed to renting. However, it is interesting how this new sharing economy co-exists with older practices of exchange and sharing coming from socialist times and familiar to the older generations.

\subsection{CONCLUSION}

In this chapter, we have approached digital consumption as consumption mediated by the Internet and analyzed it at the level of market transformations, changes in technological infrastructures and solutions, and in the activities of multiple actors (governments, retailers, professional associations, IT companies, consumers). To study digital consumption thus meant to focus on market developments (retail formats, retail culture, business models for companies), 
regulatory aspects (laws and regulations provided by the governments), technological infrastructure (possibilities and limitations of platforms, IT solutions for data collection and analysis, IT solutions to address the needs of retailing and consumers) and consumer behavior (patterns, objects and channels of purchases, online brand communities).

The key impact of digitalization of consumption in Russia by the end of the 2010s has been the swift growth of online retail platforms, such as Wildberries. ru, which have a potential of becoming global, as well as of sharing economy platforms, such as Avito.ru and Darudar.ru, aimed at arranging circulation of goods and services. Offline retail has evolved in the direction of omnichannel retailing by developing various online solutions aimed at creating, on the one hand, fast and convenient and, on the other hand, an immersive and customized experience of shopping. The interest of government in regulating this quickly developing sphere, in cross-border shopping, particularly with its potential tax revenues, has been observed. In terms of consumer practices, Russian consumers have been turning to online shopping in search of lower prices and a wider selection of goods. Initially, the average Russian online consumer's income and education were higher than the country's average, but recently, consumers from lower income and education and from older age groups have been joining the practice of online shopping more actively. This last development might be attributed, on the one hand, to personal income drops, but, on the other, to positive developments in terms of delivery or pick-up options across the country as well as saturation of internet connectivity. Overall, online shopping trends in Russia are heterogeneous due to sharp differences across Russian regions.

We would like to suggest the following directions for future research: first, more ethnographic research on the shifts in the culture of consumption caused by digital transformations is needed. Here, such diverse topics as online brand and consumer communities, how they function and shape consumer identities, and new forms of socialities and consumer behavior in Russia are to be addressed. Another research direction could be based on the use of big data on consumption in cooperation with companies. This might help in studying the peculiarities of consumer behavior of various social groups depending on different factors, such as time and place. A third direction could be a more nuanced research on tastes, social characteristics and consumer practices, based on data collected by retailers. The researchers could also take a holistic approach by examining the intersection of various aspects of digital consumption, for example overlaps between regulations, retail, technology, and consumer behavior.

\section{Notes}

1. This is the term from the professional field of retailing.

2. According to a Deutsche Bank report on prices in 2017, Russia was the third most expensive country for buying an iPhone 7 . The report was accessed on December 2018. https://www.finews.ch/images/download/Mapping.the. worlds.prices.2017.pdf. 


\section{REFERENCES}

Bocharova, Ekaterina, and Olga Echevskaya. 2014. Kollaborativnoe potreblenie v sovremennoj Rossii: formy organizacii praktiki i vklûčeniâ na primere soobŝestva Darudar [Collaborative Consumption in Contemporary Russia: Forms of Organization and Practices of Engagement Using Community Darudar as an Example]. Labirint, no. 2: 97-108.

Botsman, Rachel, and Roo Rogers. 2010. What's Mine Is Yours: The Rise of Collaborative Consumption. New York: HarperCollins books.

Dacko, Scott G. 2017. Enabling Smart Retail Settings via Mobile Augmented Reality Shopping Apps. Technological Forecasting and Social Change 124: 243-256.

Data Insight. 2014. Internet-torgovlâ v Rossii 2014. Godovoj otčet [Online Retail in Russia 2014, Annual Report]. http://www.datainsight.ru/files/DI_InSales_PayUEcommerce2014.pdf. Accessed 28 Dec 2018.

- 2017. Internet-torgovlâ v Rossii 2017. Cifry i fakty [Online Retail in Russia 2017, Figures and Facts]. https://s3.amazonaws.com/wix-anyfile/r2G6e4KrTTqbdH7EU7iB_Data\%20Insight_2017_Электронная\%20торговля.pdf. Accessed 28 Dec 2018.

. 2018. Socseti, messendžery, sajty ob”âvlenij i sharing economy kak kanaly prodaž [Social Media Platforms, Messengers, Classifieds Sites and Sharing Economy as Retail Channels]. http://www.datainsight.ru/sites/default/files/ DI-SocCommerce-YandexKassa.pdf. Accessed 28 Dec 2018.

- 2019. Rejting top-100 krupnejših internet-magazinov Rossii (za 2018 god) [Top-100 Largest Internet Retailers in Russia (as for 2018)]. http://datainsight.ru/ topl00/. c

Daviy Anna O., and Vera A. Rebiazina. 2015. Investigating Barriers and Drivers of the E-commerce Market in Russia. Working Paper. Series: Management. National Research University - Higher School of Economics.

Daviy, Anna O., Vera A. Rebiazina, and Maria M. Smirnova. 2018. Bar'ery i drajvery pri soveršenii internet-pokupok v Rossii: rezul'taty èmpiričeskogo issledovaniâ. Vestnik SPBGU. Menedžment 17 (1): 69-98.

van Deursen, Alexander J.M., Jan A.G.M. Dijk, and Oscar Peters. 2011. Rethinking Internet Skills: The Contribution of Gender, Age, Education, Internet Experience, an Hour Online to Medium- and Content-Related Internet Skills. Poetics 39: 125-144.

van Dijk, Johannes A.G.M., and Kenneth Hacker. 2003. The Digital Divide as a Complex and Dynamic Phenomenon. The Information Society 19: 315-327.

Doern, Rachel R., and Carl F. Fey. 2006. E-commerce Developments and Strategies for Value Creation: The Case of Russia. Journal of World Business 41: 315-327.

East-West Digital News. 2017. E-commerce in Russia, What International Merchants, Service Providers and Entrepreneurs Must Know to Succeed in Fast-Changing Market. http://www.ewdn.com/files/etail.pdf. Accessed 28 Dec 2018.

—. 2018. http://www.ewdn.com/2018/10/03/german-retailers-leave-russia/. Accessed 28 Dec 2018.

Ecommerce Foundation. 2018. Ecommerce Report Russia 2018. https://www.ecommercewiki.org/reports. Accessed 28 Dec 2018.

Egorova, Kira. 2017. Russians Weather the Crisis by Sharing Beds, Rides and Jobs. Russia Beyond. January 30, 2017. https://www.rbth.com/business/2017/01/30/ 
russians-weather-the-crisis-by-sharing-beds-rides-and-jobs_692088.

Accessed 28 Dec 2018.

Fashion United. 2014. KupiVIP: Lûdi stali pokupat' ne men'še, a umnee [KupiVip: People Have Started to Buy Less, But Smarter]. Fashion United, September 9, 2014. https://fashionunited.ru/vl/fashion/kupivip-ludi-stali-pokupat-umnee. Accessed 8 Sept 2018.

Firsova, Natalya. 2013. Prediktory innovacionnyh potrebitel'skih praktik: osvoenie internet-šopinga $\mathrm{v}$ rossijskih domohozâjstvah [The Predictors of Innovative Consumers' Practices: Uptaking the Internet Shopping Within the Russian Households]. Journal of Economic Sociology 14 (4): 27-57.

Ganzhur, Elena. 2019. Bakal'čuk protiv Bezosa: Wildberries budet konkurirovat' s Amazon [Bakalchuk vs Bezos. Wildberries Will Compete Against Amazon]. Forbes, March 14, 2019. https://www.forbes.ru/biznes/373327-bakalchuk-protivbezosa-gde-wildberries-budet-konkurirovat-s-amazon. Accessed 14 Apr 2019.

Gurova, Olga, and Daria Morozova. 2018. Creative Precarity? Young Fashion Designers as Entrepreneurs in Russia. Cultural Studies 32 (5): 704-726.

Hamari, Juho, Sjöklint Mimmi, and Antti Ukkonen. 2015. The Sharing Economy: Why People Participate in Collaborative Consumption. Journal of the Association for Information Science and Technology 67 (9): 2047-2059.

Hawk, Stephen. 2002. The Development of Russian E-commerce: The Case of Ozon. Management Decision 40 (7): 702-709.

- 2004. A Comparison of B2C E-Commerce in Developing Countries. Electronic Commerce Research 4 (3): 181-199.

Henni, Adrien. 2017. Yandex and Sberbank Agree \$500 Million JV Plan to Create "Leading E-commerce Ecosystem" in Russia. http://www.ewdn. com/2017/08/09/yandex-and-sberbank-agree-500-million-jv-plan-to-createleading-e-commerce-ecosystem-in-russia/. Accessed 28 Dec 2018.

- 2018. Alibaba and Mail.Ru Group Join Forces to Create "One-Stop Platform for Social, Communications, Gaming and Shopping." http://www.ewdn. com/2018/09/11/alibaba-and-mail-ru-group-join-forces-to-create-one-stopplatform-for-social-communications-gaming-and-shopping/.

Accessed 28 Dec 2018.

Hunter, Julie, and Mark Wilson. 2015. Cross-Border Online Shopping Within the EU. Learning from Consumer Experience. http://www.anec.eu/attachments/ ANEC-RT-2015-SERV-005.pdf. Accessed 28 Dec 2018.

Intellinews. 2019. Russian Online Retailer Wildberries posts $85 \%$ Growth in Revenues in 1Q19. Intellinews. Intellinews, April 12, 2019. https://www.intellinews.com/ russian-online-retailer-wildberries-posts-85-growth-in-revenues-in1q19-159491/?source=russia. Accessed 13 Apr 2019.

Invesp Consulting. 2016. Cross Border Shopping: Statistics and Trends. https://www. invespcro.com/blog/cross-border-shopping/. Accessed 28 Dec 2018.

Ipiev, Temir. 2018. Trendy rossijskih e-commerce platežej - 2018: analiz statistiki [Trends of Russian E-commerce Payments: Analysis of Statistics]. https://vc.ru/ trade/45487-trendy-rossiyskih-e-commerce-platezhey-2018-analiz-statistiki. Accessed 25 Dec 2018.

Ishchenko, Natalia. 2018. 'Perekrestok' zapuskaet 'marketplejs' dlâ onlajn-magazina [Perekrestok Launches a 'Marketplace' for an Online Shop]. Vedomosti, July 20, 2018. https://www.vedomosti.ru/business/articles/2018/07/20/776030-perekrestok-zapuskaet. Accessed 24 Apr 2018. 
Ishunkina, Inessa. 2018. Digital. Auditoriâ Interneta [Digital. The Internet Audience]. Mediascope. https://mediascope.net/upload/iblock/ea0/RIW2018_I-Ishunkina_ 21.11.2018.pdf. Accessed 13 Apr 2019.

Ivanenko, E.A., M.A. Koretskaja, and E.V. Savenkova. 2014. Darudar. Žizn' i smert' prostyh veŝej [Darudar. Life and Death of Ordinary Things]. In Sila prostyh vêsej, ed. S.A. Lishaeva, 137-161. St. Petersburg: Aleteja.

de Kervenoael, Ronan, Domen Bajde, and Alexandre Schwob. 2018. Liquid Retail: Cultural Perspectives on Marketplace Transformation. Consumption, Markets and Culture 21 (5): 417-422.

Kim, Eungkyu, Roman Urunov, and Hyungjoon Kim. 2016. The Effects of National Culture Values on Consumer Acceptance of E-commerce: Online Shoppers in Russia. Procedia Computer Science 91: 966-970.

Kommersant. 2018a. Lamoda primerâet magaziny. Internet-ritejler vyhodit oflajn [Lamoda Is Testing Out the Shops. Internet Retailer Is Heading Offline]. Kommersant, June 29, 2018. https://www.kommersant.ru/doc/3670886. Accessed 27 Dec 2018.

- 2018b. 'Neinteresno prodavat' to, čto proizvedeno v Kitae i zavozitsâ bez nalogov.' Sovladelec Wildberries Vladislav Bakal'čuk ob osobennostâh rossijskogo onlajn-ritejla ['It's Boring to Sell Goods Made in China and Delivered Across the Border Untaxed.' Co-owner of Wildberries Vladislav Bakalchuk on Peculiarities of Russian Online-Retail]. Kommersant, March 30, 2018. https://www.kommersant. $\mathrm{ru} / \mathrm{doc} / 3586567$. Accessed 28 Dec 2018.

- 2018c. U Wildberries srabotal assortiment. Internet ritejler otčitalsâ o rekordnoj vyručke [Assortment Has Been Pivotal in Wildberries' Case. The Internet Retailer Has Reported on Record-Breaking Profits]. Kommersant, December 17, 2018. https://www.kommersant.ru/doc/3833542. Accessed 28 Dec 2018.

- $2018 \mathrm{~d}$. V posylki podkladyvaût NDS [VAT Is Being Added into the Parcels]. Kommersant, September 15, 2018. https://www.kommersant.ru/doc/3410434. Accessed 22 Dec 2018.

- 2019. Wildberries v I kvartale 2019 goda uveličil oborot na 85\% [Wildberries Show 85\% Turnover Growth in the I Quarter of 2019]. Kommersant, April 11, 2019. https://www.kommersant.ru/doc/3940021. Accessed 13 Apr 2019.

Kozinets, Robert V. 2010. Netnography: Doing Ethnographic Research Online. Sage Publications.

Mediascope. 2019. Statistics on Avito.ru. January 2019. https://webindex.mediascope .net $/$ report byGeo $=1 \&$ byDevice $=3 \&$ byDevice $=1$ \&byDevice $=2 \&$ byMont $\mathrm{h}=201901$ \&id=15828. Accessed 12 Apr 2019.

Mihajlova, Lera. 2018. Glava servisa arendy vê̂ej Rentmania rešil perevesti servis v SŠA iz-za otsutstviâ finansirovaniâ v Rossii [The Head of Renting Service Rentmania Has Decided to Move the Service the USA Due to Lack of Financing in Russia]. https:// vc.ru/flood/38904-glava-servisa-arendy-veshchey-rentmania-reshil-perevezti-servis-v-ssha-iz-za-otsutstviya-finansirovaniya-v-rossii. Accessed 28 Dec 2018.

Morgan Stanley. 2018. Russia Ecommerce: Last But Not Least. https://www.cematrussia.ru/news/expo/6890-morgan-stanley-ru-ecom-internet.pdf. Accessed 28 Dec 2018.

Pantano, Eleonora, and Alessandro Gandini. 2018. Shopping as a 'Networked Experience': An Emerging Framework in the Retail Industry. International Journal of Retail \& Distribution Management 46 (7): 690-704. https://doi.org/10.1108/ ijrdm-01-2018-0024. 
PayPal Inc. 2018. Cross Border Consumer Research 2018. https://www.paypalobjects.com/digitalassets/c/website/marketing/global/shared/global/mediaresources/documents/PayPal_Insights_2018_Global_Report.pdf. Accessed 28 Dec 2018.

Pine, Joseph B., and James Gilmore. 1998. Welcome to the Experience Economy. Harvard Business Review, July-August, 1998. https://hbr.org/1998/07/ welcome-to-the-experience-economy.

Polukhina, Elizaveta, and Anna Strelnikova. 2014. Ot izbytočnogo potrebleniâ - k ustojčivomu: fenomen onlajn daroobmena [From Overconsumption to Sustainable Consumption: The Phenomena of Free Online Exchange]. Labirint, no. 2: 87-96.

- 2015. Exploring the Russian Online Gift-Exchange Communities: The Results of Netnographic Approach. The Qualitative Report 20 (12): 2041-2049.

Popova, Natalia. 2019. Wildberries obošël H\&M i Zara po ob"emu trafika sredi onlajnmagazinov odeždy [Wildberries Outpaced H\&M and Zara in the Amount of Traffic Volume Among Fashion Online Retailers]. FashionUnited, March 12. https://fashionunited.ru/novostee/reetyeil/wildberries-oboshel-h-m-i-zara-po-obemu-trafikasredi-onlajn-magazinov-odezhdy/2019031225091?fbclid=IwAR0siPJGk5Mwujutr hs7PqG53sKVb0nbpD7bVuqQiGgupu0aQyOX5909gPg. Accessed 13 Apr 2019.

Radon, Anita. 2012. Counterfeit Luxury Goods Online: An Investigation of Consumer Perceptions. International Journal of Marketing Studies 4 (2): 74-79.

Rebiazina, Vera A., Anastasia V. Shalaeva, and Maria Smirnova. 2018. Do Russian Consumers Understand and Accept the Sharing Economy as a New Digital Business Model? In Digital Transformation and Global Society, 386-401. Cham: Springer.

Rigby, Darrell K. 2011. The Future of Shopping. Harvard Business Review, December 2011. https://hbr.org/2011/12/the-future-of-shopping.

Ruckenstein, Minna. 2017. Digital Consumption. In Routledge Handbook on Consumption, ed. Margit Keller, Bente Halkier, Terhi-Anna Wilska, and Monica Truninger, 562-575. London and New York: Routledge.

Russia Business Today. 2018. Russian Government Postpones Duty Threshold Cut for Internet Shopping Abroad. https://russiabusinesstoday.com/economy/russiangovernment-postpones-duty-threshold-cut-for-internet-shopping-abroad/. Accessed 29 Dec 2018.

Russian Association of Internet Trade Companies. 2017. Ecommerce Report Russia 2017. https://www.arvato.com/content/dam/arvato/documents/reports/russia-reports/Russian_Country\%20Report_2017_\%20Ecommerce\%20Foundation_ Arvato_Rus.pdf. Accessed 28 Dec 2018.

- 2018. Position of RAITC on the Issue of Cross-Border Shopping. http:// www.akit.ru/position-cross-border/. Accessed 22 Dec 2018.

Sadyki, Marina. 2017. National Report on E-commerce Development in Russia. Working Paper. Series: Inclusive and Sustainable Industrial Development. United Nations Industrial Development Organisation. https://www.unido.org/api/opentext/documents/download/9920890/unido-file-9920890. Accessed 28 Dec 2018.

Schor, Juliet B., and Craig J. Thompson. 2014. Sustainable Lifestyles and the Quest for Plenitude: Case Studies of the New Economy. New Haven, CT: Yale University Press.

Shlyahov, Evgenij. 2017. Velikaâ šeringovaâ revolûciâ: kak zarabotat' na arende vsego na svete [Great Sharing Revolution: How to Earn on Renting Out Everything Possible]. Biz360, January 16, 2017. https://biz360.ru/materials/kak-zarabotatna-arende-vsego-na-svete/. Accessed 28 Dec 2018. 
Skuratova, Maria. 2018. Dan' gosudarstvu: čem opasny ograničeniâ na onlajn pokupki [Custom Duties to the Government: What Is Dangerous About Limits on Online Purchases]. RBC, September 17, 2018. https://www.rbc.ru/opinions/own_busin ess/17/09/2018/5b9b9f8b9a7947cb8f082ble. Accessed 22 Dec 2018.

Strelnikova, Anna, and Elizaveta Polukhina. 2014. 'Čto takoe povsemestnoe darenie? Èto maksimal'noe doverie drug k drugu': osobennosti social'nogo porâdka v virtual'nyh soobŝestvah daroobmena ['What Is All-Around Gift-Giving? This Is the Highest Possible Level of Trust Towards Each Other': Peculiarities of Social Order in Virtual Gift-Giving Communities]. Inter, no. 7: 7-21.

Sun, Leo. 2018. JD.com Could Be Returning to Russia. The Motley Fool, July 5, 2018. https://www.fool.com/investing/2018/07/05/jdcom-could-be-returning-torussia.aspx. Accessed 28 Dec 2018.

TASS. 2017. 'Nalog na Alièkspress': smogut li rossiâne delat' pokupki v onlajn magazinah? ['Aliexpress Tax': Will Russians Be Able to Shop in Online Shops?]. TASS, September 15, 2017. https:/ / tass.ru/ekonomika/4564606. Accessed 27 Dec 2018.

Tishina, Yuliya. 2018. Onlajn pokupki ne otličaûtsâ original'nost'û: rossiâne vybiraût kontrafakt [Online Purchases Are Not Quite Unconventional: Russians Do Choose Pirate Goods]. Kommersant, December 21, 2018. https://www.kommersant.ru/ doc/3836670. Accessed 14 Apr 2019.

Treapăt, Laurentiu-Mihai, Gheorghiu Anda, and Marina Ochkovskaya. 2018. A Synthesis of the Sharing Economy in Romania and Russia. In Knowledge Management in the Sharing Economy, ed. Elena-Mădălina Vătămănescu and Florina Pînzaru, 57-73. Springer: Cham.

Urbanovsky, Tomas. 2015. Factors Behind the Russian Ruble Depreciation. Procedia Economics and Finance 26: 242-248. https://doi.org/10.1016/S2212-5671 (15)00827-8.

Utesheva, Galina. 2018. Offlajn ne umret: 4 trenda radikal'noj transformacii šopinga [Offline Will Not Die: 4 Trends of Shopping Radical Transformation]. Fashion United, December 24, 2018. https://fashionunited.ru/novostee/reetyeil/oflajn-ne-umret4-trenda-radikalnoj-transformatsii-shopinga/2018122424347. 25 Dec 2018.

Vedomosti. 2017. Alièxpress oprobuet v Rossii magaziny virtual'noj real'nosti [Aliexpress Will Test Virtual Reality Stores in Russia]. Vedomosti, November 3, 2017. https://www.vedomosti.ru/business/news/2017/11/03/740493-aliexpress-virtualnoi-realnosti. Accessed 27 Dec 2018.

Wahlen, Stefan, and Mikko Laamanen. 2017. Collaborative Consumption and Sharing Economy. In Routledge Handbook on Consumption, ed. Margit Keller, Bente Halkier, Terhi-Anna Wilska, and Monica Truninger, 94-105. London and New York: Routledge.

Yandex. 2016. Razvitie rozničnoj online torgovli v Rossii [Development of Online Retail Trade in Russia]. Yandex, December 21, 2016. https://yandex.ru/company/researches/2016/ya_market_gfk. Accessed 28 Dec 2018.

Yandex Kassa and Data Insight. 2018. Pokupki i pokupateli v social'nyh setâh, messendžerah, na sajtah ob"âvlenij i šaring economy [Purchases and Customers in Social Media, Messengers, on Classified Sites and Sharing Economy]. Yandex Kassa and Data Insight, December 26, 2018. http://datainsight.ru/sites/default/files/ ecombehavior.pdf. Accessed 12 Jan 2019.

Zhang, Autumn. 2018. 2017 Statistics on the Chinese Cross-Border Online Shopping Market. Eggplantdigital, May 21, 2018. https://eggplantdigital.cn/2017-statistics-on-the-chinese-cross-border-online-shopping-market/. Accessed 28 Dec 2018. 
Open Access This chapter is licensed under the terms of the Creative Commons Attribution 4.0 International License (http://creativecommons.org/licenses/ by $/ 4.0 /)$, which permits use, sharing, adaptation, distribution and reproduction in any medium or format, as long as you give appropriate credit to the original author(s) and the source, provide a link to the Creative Commons licence and indicate if changes were made.

The images or other third party material in this chapter are included in the chapter's Creative Commons licence, unless indicated otherwise in a credit line to the material. If material is not included in the chapter's Creative Commons licence and your intended use is not permitted by statutory regulation or exceeds the permitted use, you will need to obtain permission directly from the copyright holder. 